Kunuz: Journal of Islamic Banking and Finance Vol. 1, No.2 (2021):74-84

Website: http://ejournal.iain-manado.ac.id/index.php/kunuz

ISSN 2807-615X (online) ISSN 2807-680X (print)

\title{
IMPLEMENTATION OF MURABAHAH CONTRACTS IN BUYING AND SELLING HOUSING
}

\author{
Nivia Mina Audria* \\ Fakultas Ekonomi dan Bisnis Islam, Institut Agama Islam Negeri \\ Pekalongan (IAIN), Jawa Tengah, Indonesia, Jl. Pahlawan No.52 Kajen, \\ Kabupaten Pekalongan, 51161 \\ E-mail: niviaminaaudria@mhs.iainpekalongan.ac.id \\ Hendri Hermawan Adinugraha \\ Fakultas Ekonomi dan Bisnis Islam, Institut Agama Islam Negeri \\ Pekalongan (IAIN), Jawa Tengah, Indonesia, Jl. Pahlawan No.52 Kajen, \\ Kabupaten Pekalongan, 51161 \\ E-mail: hendri.hermawan@,iainpekalongan.ac.id
}

*Correspondance

\begin{abstract}
Indonesia's economic development related to the demand for housing is increasing. Many indicators can be seen in the community, such as the number of community housing developments. These developments create property business opportunities such as buying and selling housing, especially those that avoid the element of usury so that they look for a sharia buying and selling process, one of which is a murabahah contract. This study aims to determine the implementation of the murabahah contract in buying and selling housing. This research is descriptive research based on a literature study. Data collection is done by taking from literature sources that are relevant to the research problem. Based on the analysis of various literature, this study concludes that in the implementation of buying and selling murabahah contracts, it is required that both parties must know the benefits that have been agreed upon, and the element of usury is prohibited. In its implementation, it must meet the pillars and conditions according to sharia principles. Traded goods are not included in the categories prohibited by Islamic law. But there are some in the implementation of the murabahah contract, there are some that have been modified related to the murabahah contract.
\end{abstract}

Keywords: Buying and Selling; Housing; Murabahah Contract 


\section{Kunuz: Journal of Islamic Banking and Finance Vol. 1, No.2 (2021):75-84 Website: http://ejournal.iain-manado.ac.id/index.php/kunuz ISSN 2807-615X (online) ISSN 2807-680X (print)}

\section{INTRODUCTION}

The development of the property business in Indonesia has experienced a significant increase in the last decade. The need for a house as a place to live is increasing along with economic developments that occur in Indonesia. Many indicators can be seen in the community, for example with the number of community residential developments. Even the need for housing as a place to live has become a primary need (F. Nur, 2020). Home is the basic need of every person besides food and clothing. The house has a very important function for human life (Rochman et al., 2019).

Facts about sharia property because it has many enthusiasts and tempting sales of sharia property, lately many irresponsible people deceive consumers under the guise of selling sharia properties (Tridya, 2021).

Indonesia as stipulated in Article 28 Paragraph 1 of the 1945 Constitution of the Republic of Indonesia, is the right of everyone to live, live in physical and spiritual prosperity, and have a good and healthy living environment. Therefore, the house as an individual residence or social system is the right of everyone, whether in the form of a family or not (Nurani \& Ali, 2019).

With the development of the times, the population is increasing. This affects the scope of the community to determine where to live. The development of settlements, both rural and urban, is to realize livable, comfortable, and prosperous houses. However, some people have insufficient financial conditions to have a place to live due to several factors, one of which is the high price of land.

There are many ways to get a place to live, one of which is an agreement on sufficient funds. Paying a house in cash and cash is the best and wise way (AlHakiki, 2019). One of the most basic human needs is a place to live. In addition to food and clothing, the house as a place to live is one of the basic human needs. Everyone needs a house as a stopover place, as a gathering place for family activities, and as an investment (Lorenza, 2021). The problem of housing and settlements is an important issue that is getting more attention from the government. The problem of housing and settlements is a problem that continues and increases with the increase in population, vital statistics, and socio-economic demands.

Islam is a perfect religion, in Islam, it pays attention to aspects of human problems so that it is studied and considered. Allah SWT has developed and perfected all forms of rules that are used as guidelines for all Muslims. The same applies to Muamara in special trading activities based on murabahah contracts (Lembaga et al., 1980).

Originally, the law of buying and selling itself is permissible or permissible and has been confirmed by Al-Imam Asy-Syafi'i that the law of buying and selling is entirely permissible, that is, if it is with the pleasure of both the buyer and the seller (Sarwat, 2018). Muamalah that is often carried out by humans with other humans is buying and selling. Buying and selling cannot be separated from the contract. In Islam, several types of trading are allowed, one of which is murabahah. 


\section{Kunuz: Journal of Islamic Banking and Finance Vol. 1, No.2 (2021):75-84 Website: http://ejournal.iain-manado.ac.id/index.php/kunuz ISSN 2807-615X (online) ISSN 2807-680X (print)}

Murabahah is a form of the sales contract that adds a certain amount of profit (margin) to the cost of a product. Financing based on this Murabaha contract can be done in cash or with deferred payments or installments (Lubis, 2018).

Murabahah is a sale and purchase contract for certain goods, in which the seller explains the goods to be sold very clearly regarding the purchase price of the goods to the buyer, which in the process explains the conditions for a certain amount of profit or profit (Prihantono, 2018). In Murabaha, the seller tells the buyer the purchase price of the goods and sets a certain amount of profit. In simple terms, buying and selling murabahah means selling a product at a price, namely the price of the product (cost of goods) plus the agreed profit (Damayanti, 2018).

The research that the author chose was the implementation of murabahah contracts in buying and selling housing related to murabahah against the background of many people who wanted a place to live but lacked funds so that they needed housing loan assistance following the principles of buying and selling sharia. If the housing to be studied uses the principle of buying and selling sharia, it can help the community in carrying out and improving welfare and various activities, especially basic needs, namely housing, especially buying and selling following Islamic teachings. In the community, it is assumed that Islamic banking and conventional banking both apply the principle of interest. Misperceptions of the public regarding muamalah activities, murabahah contracts, and credit installments at conventional banks, even though both have different principles (Amin, 2016).

The contract that has received many assessments regarding the halalness of its implementation is murabahah, namely buying and selling at a selling price consisting of the purchase price and the agreed profit (Antonio, 2001). Misperceptions related to murabahah that cause people to think the same as a credit at conventional banks. Murabahah is often equated with a credit agreement but only changed its name to a murabahah or sale-purchase contract. This is due to a change in the practice of murabahah credit which is based on the similarity of credit practices that are imitated by conventional banks. In fact, in addition to the high selling price compared to conventional bank loan applications and installment payments and the implementation process, there is no difference between murabahah and ordinary credit (Wahyu \& Abdullah, 2017). Muamalah activities must use provisions that are following the principles and methods of muamalah.

In reality, collecting margin in Islamic banks is similar to collecting interest in conventional banks. This is also caused by the credit payment system. This method raises the public opinion that Islamic banks are generally the same as conventional banks. So the opinion that Islamic banks are the same as conventional banks is not only for the general public but also for intellectuals (Jumriah, 2020).

Murabaha requirements include the need for banks and customers to enter into usury-free murabaha contracts. Traded goods are not included in the 


\section{Kunuz: Journal of Islamic Banking and Finance Vol. 1, No.2 (2021):75-84 Website: http://ejournal.iain-manado.ac.id/index.php/kunuz ISSN 2807-615X (online) ISSN 2807-680X (print)}

categories prohibited by Islamic law. The bank must mediate all matters relating to the purchase. For example, if the purchase is made based on debt, the bank sells the goods to the customer (customer) at a selling price equal to the purchase price plus profit. The customer pays the agreed price according to the agreed term. Banks can prevent abuse and contract damage through additional contracts with their customers. When representing a customer when purchasing goods from a third party, the bank and the customer must sign a riba-free Murabaha contract. Traded goods are not included in the categories prohibited by Islamic law (Meirani et al., 2020). Based on the problems above, the researcher considers it important to conduct further research on the implementation of murabahah contracts in buying and selling housing.

\section{RESEARCH METHODS}

This research is descriptive in the form of library research by conducting discussions based on books and other literature as a reference source of research (Arikunto, 2013). The analysis used is a descriptive method by providing an overview related to the implementation of the murabahah contract in buying and selling housing. The research steps taken are to collect data from reference library sources, then classify and describe the data for comparison and conclusion. The data collection method is based on references from journal articles, books, and search sources on the internet.

Literature technique is "library research carried out by reading, studying and recording various literature or reading materials that are following the subject matter, then filtered and poured into a theoretical framework". This technique is carried out to strengthen the facts to compare the differences and or similarities between theory and practice that the author is currently researching regarding the implementation of murabahah contracts in buying and selling housing (Leo, 2017). This technique is used by researchers to get results according to research problems through library techniques.

\section{RESULTS AND DISCUSSION}

According to the scholars of fiqh, the contract is the relationship between consent and qabul following the will of the Shari'a which stipulates the existence of legal influence (consequences) in the object of the engagement. According to the scholars of the compilation of sharia economic law, a contract is an agreement in an agreement between two or more parties to perform and or not to perform certain legal acts (Nurlita, 2019).In the contract there is harmony. The pillars are the elements that make up the contract, consisting of (1) The parties; (2) Statement of will; (3) Aim.

With the existence of these pillars, the contract has been formed, but to function the formed contract must be fulfilled again, otherwise, it does not yet have a syar'i juridical form. The terms of the contract consist of four kinds, namely: (1) Conditions for the formation of a contract. Among others: Tamyiz, Multiple parties, Approval of Ijab Kabul (Agreement), The suitability of the 


\section{Kunuz: Journal of Islamic Banking and Finance Vol. 1, No.2 (2021):75-84 Website: http://ejournal.iain-manado.ac.id/index.php/kunuz ISSN 2807-615X (online) ISSN 2807-680X (print)}

contract assembly, The object can be submitted; legal conditions (perfect) do not cause harm, (no imperfect), The object is certain or can be determined; Certain conditions are required not to contain gharar, if there is gharar Fasid contract, The object is transactable (value); in it, there are conditions free from gharar and Free from usury. And lastly, the purpose of the contract does not conflict with sharia.

(2) Conditions for Validity of the Contract, the contract that is formed and takes the form of a syar'i juridical is not necessarily valid, then to complete it requires valid conditions: The first condition, does not require a perfect condition, The second condition according to Jumhur is that the agreement/agreement must be reached freely, even though the legal consequences depend on it, (object) submission is required not to cause harm, if it causes a loss the contract is fasid. And certain objects are required not to contain gharar, if there is gharar, then the contract is fasid.

(3) Conditions for the Validity of the Contract. A contract that is formed, and takes the form of a syar'i juridical, and is valid, it is not certain that the legal consequences can be implemented (mawquf contract/depending). For this reason, the following conditions are needed, namely: There is the authority over the object and $\mathrm{He}$ has the authority to act legally; Authority over the object is required Because there is ownership perfect over the object or the existence of an authorized representative. Meanwhile, the authority to act legally is obtained because of legal skill/tamyiz.

(4) Conditions for joining the contract, The contract that has been formed and is in the form of a syar'i juridical and valid, it is not certain that the legal consequences can be implemented, basically, it already has the binding legal force to the parties, meaning that no party can cancel it. However, because the nature of the contract is not binding even though there are enough conditions, then there are parties who can cancel it, such as a pawn agreement, specifically for accepting a pledge, it can cancel the contract. And in the dependent contract (kafalah), the creditor (credit provider/bank) can cancel the dependent contract. Or because certain contracts apply khiyar rights (such as buying and selling), this condition is called the al-luzum condition. (Sandang, 2019)

According to Fiqh scholars, every contract has legal consequences. In other words, the achievement of goals that must be achieved from the start. Every contract made by the trading party has a basic goal to be achieved. Transfer of ownership in the contract of sale, beneficial ownership of the lessee in the Ijarah (lease) contract, the right to retain the goods in the rahn contract, etc. Closing the contract creates rights and obligations between the parties to the contract. For example, when buying or selling, the buyer is obligated to estimate money as the price of the business goods and is entitled to receive the goods. Meanwhile, the seller is obliged to deliver the goods and is entitled to receive money as compensation for the goods. Likewise, other contracts must have legal consequences following the form of the contract made by both parties (Sa'diyah, 2019). 


\section{Kunuz: Journal of Islamic Banking and Finance Vol. 1, No.2 (2021):75-84 Website: http://ejournal.iain-manado.ac.id/index.php/kunuz ISSN 2807-615X (online) ISSN 2807-680X (print)}

Murabaha is a form of selling that is allowed. Murabahah describes a sales transaction where the selling price is the total cost incurred to bring in the object of the transaction (purchase cost). and the desired profit from the selling price and amount is known to the buyer in the sense that the purchase price and the desired additional profit are notified to the buyer (M. Nur, 2020).

As a form of buying and selling, the basis on which murabahah is based is the same as the basis for buying and selling in general, both in the form of verses, hadith, and ijma'. The basis of Murabaha according to the scholars states that it is permissible to buy and sell using murabaha. The basis of Murabaha from Ijma is the original law in all forms of muamalah, which is something that is allowed to be done unless there is an argument that prohibits it (Afiah et al., 2021).

Murabahah is a transaction of selling goods by stating the cost and profit (margin) agreed upon by the seller and the buyer. the sale and purchase contract can be made in cash or tough. The thing that distinguishes murabahah from other buying and selling is that the seller must start to the buyer the price of the basic goods sold and provide the profits.

Sales can be made in cash or deferred, if it is necessary to separate the profit and the cost of profit, the profit cannot be changed as long as the contract is difficult to pay, restructuring can be carried out and if the difficulty in paying is due to negligence, a fine can be imposed. The fine will be considered a benevolent fund. Advances are also acceptable but must be considered a reduction in accounts receivable.

The conditions for murabaha include the following: (1)The seller informs the customer of the cost of capital; (2) The first contract must be valid following the stipulated pillars; (3) The contract must be free from usury; (4) The contract must explain to the buyer if there is a defect in the goods after purchase. (5) The seller must convey all matters relating to the purchase, for example, if the purchase is made on the debt.

In murabahah transactions, the terms and pillars must be fulfilled following Islamic law. As the Messenger of Allah SWT has taught others that when he trades, he is always honest and transparent (Wantoro, 2018).In simple terms, murabahah means a sale of goods at that price plus an agreed profit, for example, someone buys goods and then resells them at a certain profit. How much profit can be expressed in a certain nominal rupiah or the form of a percentage of the purchase price, for example, $10 \%$, or $20 \%$ ?

Murabahah can be categorized: First, Murabahah without orders is a principle where murabahah is whether there is an order or not, the bank provides the merchandise. However, the supply of these goods is not affected or directly related to whether or not there are orders or buyers. Second, murabahah with orders, where the seller buys the goods after there is an order from the buyer. Murabaha with an order can bind or not bind the buyer to buy the ordered goods. Because it is binding, it means that the buyer must buy the ordered item and cannot cancel the order (Yuranda \& Daud, 2019).

The buyer's agreement in Murabaha based on an order is either binding or 


\section{Kunuz: Journal of Islamic Banking and Finance Vol. 1, No.2 (2021):75-84 Website: http://ejournal.iain-manado.ac.id/index.php/kunuz ISSN 2807-615X (online) ISSN 2807-680X (print)}

non-binding. This means that if a customer or customer places an order for goods, but the customer is not bound, but the order must be purchased without obligation, the customer can accept or cancel the goods. On the other hand, in terms of payment methods, Murabaha can be in the form of cash or deferred payments. Many Islamic banks currently operate Murabaha, which is based on orders with a deferred nature and method of payment (Wantoro, 2018).

Buying and selling are one of the terms of fiqh whose provisions are contained in the Qur'an and As-Sunnah, which from a historical point of view are a continuation of the Shari'a before the teachings of Islam was revealed to the Prophet Muhammad. Hanafiah scholars explain that the purpose of buying and selling in terminology is the exchange of property in particular, or the exchange of something that is desired to be useful (mufid) in a special way, namely consent and qabul.

The legal basis for buying and selling (selling and buying) was originally permissible (permissible), but the law can change to be obligatory, unlawful, sunnah, or makru, depending on the circumstances and conditions, depending on the benefit. One of the arguments that explain the source of sales law is Q.S. ALBaqarah: 257: "Allah is the protector of those who believes; He brought them out of darkness (unbelief) to light (faith). and those who disbelieve, their protectors are Satan, who brings them out of light into darkness (unbelief). they are the inhabitants of hell; they abide in it." (Q.S. AL-Baqarah: 257).

Based on this verse, Allah SWT has permitted or allowed the sale (buying and selling) and forbade usury, because it is used as a guide for Muslims in the Muamalah trade. The scholars have agreed that buying and selling are permissible because people cannot fulfill their own needs without the help of others. Islamic scholars from the time of the Prophet until today agree that buying and selling are permissible. Logically, people need other people's property, while the way to get the goods is by buying and selling processes (transactions). In Islam, there is no prohibition for everyone who wants to do anything beneficial to himself (Lorenza, 2021).

In buying and selling in Islam there are principles of buying and selling, among others, first, the principle of monotheism is this principle a Muslim entrepreneur does not exploit and stays away from buying and selling with elements of usury and to get His pleasure. Second, the principle of willingness is that both must be equally willing which is measured by the existence of consent and qabul. Third, the moral principle or ethical principle is the principle that in carrying out or buying and selling, one must have the characteristics of the Prophet and Apostle properly so that it is good in it and avoid evil in buying and selling transactions. Fourth, the principle of expediency so that the goods sold and traded must be functionally useful for the buyer. Fifth, the principle of individual freedom, in this principle a person determines an action as long as it does not violate Islamic law and in this principle, there is khiyar, namely freedom of choice. The six principles of justice are that the seller must be fair to the buyer regarding the goods being sold and neither the buyer nor the seller is unjust. The seventh 


\section{Kunuz: Journal of Islamic Banking and Finance Vol. 1, No.2 (2021):75-84 Website: http://ejournal.iain-manado.ac.id/index.php/kunuz ISSN 2807-615X (online) ISSN 2807-680X (print)}

principle of buying and selling is the principle of honesty, which is the principle where the seller must explain the goods being traded honestly without any element of fraud. The last principle, the valid principle in this principle, is that a sale is carried out by fulfilling the terms and conditions of sale and purchase (Ulum, 2020).

Buying and selling in the terminology of Islamic jurisprudence mean exchanging assets based on mutual pleasure, transferring ownership in exchange for the value given. There are 3 forms of buying and selling, namely murabahah, greeting, and istishna (Nurlita, 2019).

Murabahah buying and selling in the perspective of Islamic economics has several pillars and conditions that must be met, consisting of (1) the contracting party (Al-'aqidain). It consists of sellers (Banks), buyers (Customers), suppliers (suppliers); (2) The object of the contract (Mahallul 'Aqad) is the existence of the form of goods being traded and the price of the goods; (3) The purpose of the contract (Maudhu'ul Aqad); (4) Akad (sighat al-'Aqad), namely the existence of surrender (ijab) and acceptance (qabul).

In addition, the object and purpose of the contract must be free from elements that are prohibited by sharia and positive law, namely the maghrib element (maysir, gharar, and usury) (Kusumo \& Santi, 2021).

Housing is a basic need other than food and clothing. Therefore, to meet the needs of increasing housing and also increasing population growth, it is necessary to handle it with planning accompanied by capital, funds, and existing resources in the community. Every human being is faced with three basic needs, namely food, clothing, and shelter. The need for houses as a place to live, both in urban and rural areas continues to increase with the increase in population (Abdillah, 2021). Housing is a collection of several houses for residence. The house is needed as a place to shelter and gather with family (Rachmat et al., 2007).

Housing is a collection of houses that become a settlement, both urban and rural, housing is designed with facilities, infrastructure, and public utilities as a result of efforts to fulfill housing that is used according to needs (Andriansyah et al., 2020).

Law no. 1 of 2011 stipulates that a house can function as (1) Fulfillment of basic needs;(2) Place of residence or residence;(3) Asset (wealth) for the owner;(4) The social and economic status of the owner; (5) A place to earn income or profit; (6) A means of fostering a family, a reflection of the dignity and worth of the owner; (7)Supporting the implementation of the duties of officials and/or civil servants (Santoso, 2014).

\section{CONCLUSION}

Akad is a relationship of consent and qabul between the seller and the buyer. And housing is a house that is a place to live that is designed with facilities and infrastructure that are comfortable to live in. While the sale and purchase of this housing use the sale and purchase of a murabahah contract. In the murabahah contract, there are terms and pillars following Islamic principles, one of which is 


\section{Kunuz: Journal of Islamic Banking and Finance Vol. 1, No.2 (2021):75-84 Website: http://ejournal.iain-manado.ac.id/index.php/kunuz ISSN 2807-615X (online) ISSN 2807-680X (print)}

free from the element of usury. Murabahah contract is a contract obtained from Islam. In the sale and purchase of a murabahah contract, goods are goods that are lawful or not prohibited by religion. The implementation of the murabahah contract in the sale and purchase of housing must meet the requirements and pillars. In the implementation of the second murabahah contract, one must know that the profit from this transaction (housing sale and purchase) is a mutually agreed sale and purchase advantage, in which case the bank as the seller must notify the buyer (customer) in advance about the cost of goods purchased and include the amount of profit received. added to the cost. This is based on the literature related to the problem that the author has reviewed and read.

\section{REFERENCE}

Abdillah, I. (2021). Implementasi Akad Ba'i Istishna dan Ba'i Taqsith Pada Pembiayaan Kepemilikan Rumah (Non Bank) di Perumahan Islami Indonesia. Al-Kharaj: Jurnal Ekonomi, Keuangan \& Bisnis Syariah, 3(1).

Afiah, N., Nadhah, N., \& Haerunnisa. (2021). Praktik Jual Beli Murabahah Pada Masyarakat. Ats-Tsarwa: Jurnal Ekonomi Islam, jil 1(1).

Al-Hakiki, F. U. (2019). Tinjauan Hukum Islam Terhadap Jual Beli Rumah Di Griya A Sakinah Kecamatan Geger Kabupaten Madium. IAIN Ponorogo.

Amin, R. (2016). Dinamika penerapan murabahah dalam sistem perbankan syariah. Jurnal Perbankan Syariah, 1(1), 3.

Andriansyah, F., Haryanto, E. V., \& Saleh, A. (2020). Rancang Bangun Aplikasi Smart Security Untuk Perumahan Dengan Menggunakan Qr Code Berbasis Android. Jurnal FTIK, 1(1).

Antonio, M. S. (2001). Bank Syariah dari Teori ke Praktik. Gema Insani Press.

Arikunto, S. (2013). Prosedur Penelitian: Suatu Pendekatan Praktik. Rineka Cipta.

Damayanti, B. D. (2018). Analisis Pelaksanaan Akad Murabahah Pada KSPPS Karisma Magelang. Universitas Muhammadiyah Magelang.

Jumriah. (2020). Sistem Profit Margin Dalam Pembiyaan Perumahan Rakyat Dengan Akad Murabahah di Bank BTN Syariah Parepare. IAIN Parepare.

Kusumo, T. H. P., \& Santi, M. (2021). Implementasi Strategi Penyelesaian Pembiayaan Produk Murabahah Bermasalah (Studi Pada Bmt Muamalah Tulungagung). 14(2).

Lembaga, D. I., Keuangan, M., \& Bmt, S. (1980). Al-Quran dan Terjemah, Bandung: Diponegoro, Surat al-Maidah: 03 Muhammad Ali Al-Shabuni, Sofwah al-Tafaasir, Beirut: Dar al-Quran al-Karim, 1980, jilid I, hlm. 326.

Leo, S. (2017). Pengaruh Harga dan Promoi Terhadap Volume Penjualan Dalam Perspektif Ekonomi Islam(Studi pada CV. Anugerah Semata Bandar Lampung). UIN Raden Intan Lampung.

Lorenza, T. (2021). Tinjaunan Hukum Islam Tentang Akad Brokeragr Paralel Dalam Jual Beli Rumah(Studi Di Perumahan Mutiara HKS Kecamatan Muaradua Kabupaten Oku Selatan). Universitas Islam Negeri Raden Intan Lampung.

Lubis, T. I. A. (2018). Implementasi Akad Murabahah Pada Pembiyan KPR 


\section{Kunuz: Journal of Islamic Banking and Finance Vol. 1, No.2 (2021):75-84 Website: http://ejournal.iain-manado.ac.id/index.php/kunuz ISSN 2807-615X (online) ISSN 2807-680X (print)}

Bersubsidi FLPP(Fasilitas Likuiditas Pembiyaan Perumahan) Pada Bank Sumut Syariah Kantor Cabang Syariah Medan 2 Ringroad. Universitas Islam Negeri Sumatera Utara Medan.

Meirani, R. A., Damiri, A., \& Jalaludin, J. (2020). Penerapan Akad Murabahah pada Produk MULIA di Pegadaian Jalancagak Menurut Perspektif Ekonomi Syariah. EKSISBANK: Ekonomi Syariah Dan Bisnis Perbankan, 4(1), 60-68. https://doi.org/10.37726/ee.v4i1.69

Nur, F. (2020). Jual Beli Rumah Di Properti Syariah Dan Konvensional Perspektif Hukum Ekonomi Syariah (Studi Komparatif Di Oase Residence Dan Sapphire ).

Nur, M. (2020). Analisis Penyelesaian Sengketa Akad Murabahah (Jual-Beli) Antara Bank Syariah - X dengan PT AS di Badan Arbitrase Syariah Nasional -Majelis Ulama Indonesia (BASYARNAS-MUI). Jurnal Ilmu Pendidikan Nonformal, 6(2).

Nurani, M. F., \& Ali, A. M. (2019). Pelaksanaan Akad Murabahah pada Pembiayaan Hunian Syariah. Jurnal Riset Akuntansi Politala P-ISSN, 2(November), 38-44.

Nurlita, E. (2019). penerapan akad murabahah dalam pembiyaan pensiun(studi pada bank syariah mandiri kantor cabang Bandar Jaya) [univesitas islam negeri Raden Intan Lampung]. http://repository.radenintan.ac.id/7667/1/SKRIPSI LENGKAPfiks.pdf

Prihantono. (2018). Akad Murabahah Dan Permasalahannya Dalam Penerapan Di Lembaga Keuangan Syariah. Al Maslalah, 12(2).

Rachmat, Junarti, ., Rohmawati, Karyati, T., Mulyani, S., \& Sunarto. (2007). aku cinta Jakarta Pendidikan Lingkungan dan Budaya Jakarta untuk SD klas 5 (A. Apriliawati (ed.)). Ganeca Exact.

Rochman, A., Triasih, D., \& Abib, A. S. (2019). Tinjauan Hukum Islam Terhadap Sistem Transaksi Kredit Pemilikan Rumah (KPR) Di Bank Tabungan Negara Syariah (BTN Syariah) Semarang. Hukum Dan Masyarakat Madani, 7(3), 167. https://doi.org/10.26623/humani.v7i3.1425

Sa'diyah, M. (2019). FIQIH MUAMALAH II (Teori dan Praktik), ( purwo adi Wibowo (ed.); 1st ed.). UNISNU PRESS.

Sandang, N. P. V. (2019). Implementasi AkAd Murabahah Pada Bank Syariah Mandiri Cabang Gowa. universitas muhammadiyah Makasar.

Santoso, U. (2014). Hukum Perumahan (Pertama). Kencana.

Sarwat, A. (2018). Fiqh Jual beli. 1-56.

Tridya, D. S. (2021). Wajib Tahu! 5 fakta Mengenai Properti Syariah agar tidak Tertipu. Rumah123.Com. https:/www.rumah123.com/panduan-properti/tipsproperti-66425-5-fakta-mengenai-properi-syariah-agar-tidak-tertipu-id.html

Ulum, M. (2020). Prinsip-Prinsip Jual Beli Online Dalam Islam Dan Penerapannya Pada E-Commerce Islam Di Indonesia. Jurnal Dinamika Ekonomi Dan Bisnis, 17(1).

Wahyu, A. R. M., \& Abdullah, M. W. (2017). Penerapan Prinsip Syariah Dalam Akad Pembiyaan Murabahah Pada Bank Mualat. Jurnal Iqtisaduna, 3(1). 
Kunuz: Journal of Islamic Banking and Finance Vol. 1, No.2 (2021):75-84

Website: http://ejournal.iain-manado.ac.id/index.php/kunuz

ISSN 2807-615X (online) ISSN 2807-680X (print)

Wantoro, H. A. (2018). Implementasi Akad Murabahah Dalam Peningkatan KPR FLPP Di BRI Syariah KCP Metro. IAIN METRO.

Yuranda, A., \& Daud, R. M. (2019). Analisis Akad Pembiyaan Murabahah Perumahan (KPR) Pada PT Bank BRI Syariah KC Banda Aceh. Jurnal Ilmiah Mahasiswa Ekonomi Akuntansi, 4(1), 53. 